\title{
Crosstalk between endophytes and a plant host within information processing networks
}

\author{
N. O. Kozyrovska \\ Institute of Molecular Biology and Genetics, NAS of Ukraine \\ 150, Akademika Zabolotnogo Str., Kyiv, Ukraine, 03680 \\ kozyrna@ukr.net
}

\begin{abstract}
Plants are heavily populated by pro- and eukaryotic microorganisms and represent therefore the tremendous complexity as a biological system. This system exists as an information processing entity with rather complex processes of communication, occurring throughout the individual plant. The plant cellular information processing network constitutes the foundation for processes like growth, defense, and adaptation to the environment. Up to date, the molecular mechanisms, underlying perception, transfer, analysis, and storage of the endogenous and environmental information within the plant, remain to be fully understood. The associated microorganisms and their investment in the information conditioning are often ignored. Endophytes as plant partners are indispensable integrative part of the plant system. Diverse endophytic microorganisms comprise «normal» microbiota that plays a role in plant immunity and helps the plant system to survive in the environment (providing assistance in defense, nutrition, detoxification etc.). The role of endophytic microbiota in the processing of information may be presumed, taking into account a plant-microbial co-evolution and empirical data. Since the literature are beginning to emerge on this topic, in this article, I review key works in the field of plant-endophytes interactions in the context of information processing and represent the opinion on their putative role in plant information web under defense and the adaptation to changed conditions.
\end{abstract}

Keywords: a plant system, endophytes, information processing, plant defense, adaptation.

Plant is a complex ecosystem with a versatile communal life. The plant as all existing living entities is systemically inhabited by diverse microorganisms [13], and so far it constitutes a hierarchically complex system, displaying different genetic landscapes, interactomes, and information processing networks. The plant controls its interactions with beneficial and pathogenic microbes in the context of environmental influences, and the outcome of such interactions depends on the interacting partners and their surrounding. Individual plants have unique microbiomes, and differences in plantassociated microbiome structures occur mainly due to host genetic control. However, vertically-transferred core microbial species follow the plant host species during its evolution $[4,5]$. Micro-inhabitants interact with the plant partner in a metabolically-based manner, using own

(C) Institute of Molecular Biology and Genetics, NAS of Ukraine, 2013 «talents» of making relationships. On the first view, the interactions between partners can be described in terms of classical relationships: from obligatory symbiosis through loyal mutualism and unobtrusive commensalism to obligatory parasitism; however, plant-microbial relationships may be more specialized or variable and often depend on the phase in microbial life-time and environmental factors. Moreover, mutualists are able to short-circuit plant defense responses to enable successful colonization of the plant host, demonstrating that the boundaries between mutualists and pathogens are factitious.

A wide range of co-inhabitants create a spectrum of impacts on the plant biology. Accidentally incoming microorganisms may play a simple role of additional organic food processed by plant into valuable nutrients for heterotrophic feeding, but co-evolved inhabitants cooperate with the plant, affecting its fitness. Recrui- 
ting of the soil and rhizosphere microbes by plant system is fully reasonable, relying on cooperative tendencies in the world of living organisms [6] and a poor plasticity in the plant as a multi-cellular entity under adaptation to the changed environment in comparison with associated microbes; genetic exchange and phenotypic variation are important drivers of microbial plasticity, which are critical for microbial persistence in fluctuating environments. It is exploited by the plant, permanently selecting dual microbial partners for its programs (fighting the enemies, adaptation to the changed environment etc.). In evolution, the plant as a sessile organism has got practically additional instrument represented by microbial organisms for a tuning its behavior.

Microbes are self-sufficient unicellular organisms, however, they are united in multi-cellular populations within a species and exhibit inter-conversion between phenotypically distinct sub-populations. The latter formation depends on the surrounding, a nutrient availability, specialization etc. Cells of both heterogeneous bacterial single populations or well-organized communities of mixed populations interact for coordinated activities, i. e. populations behave as multi-cellular organisms and exhibit signs of a social entity [7]. To govern the unity of a cell population and to manipulate the substructures within species, the well balanced regulatory systems evolved, which are based on the perception and processing of information, e. g. cell-to-cell communication via regulatory molecules or physical signals. Due to coordination and synchronization, microbial organisms exhibit cooperative social behaviors, such as biofilm or persister phenotype formation, chemical defense, etc. In the plant system, the activity of associated microbiota expressed in providing bioactive compounds, which plant cannot produce, in fine-tuning plant behavior under adaptation to changed conditions, detoxication of the plant super-organism etc.

When we focus on information processing in the plant system, we cannot ignore microbial constituents, which may either serve or regulate some plant physiological processes and so far participate in its information processing networks. Especially, this may concern endophytic microorganisms, which comprise indigenous residents within the plant interior and represent a diverse part of plant-associated microbiome (reviewed in [1, $8,9]$. There are certain peculiarities in the endophy- te-plant partner co-existence: (i) endophytes are a category of microbes, that capable to cheat plant immune system in order to form populations in the plant interior without causing any harm; (ii) relaying on small-size populations restricted by a set of factors (e.g. a shortage of signaling molecules, nurients, a control by the macro-organism etc.), endophytes seem to be metabolically less active than microbes, colonizing the plant outside; (iii) the spatial structure of endophytic microbiome can strongly affect their social interactions; endophytic bacteria frequently grow in dense, multi-cellular communities in biofilms [10], however, more often a distance between their cells/populations is longer than $e$. $g$. in epiphyte microbiome.

Endophytic populations are constituted by both genotype-associated core species, which often pass through plant generations, and incoming recruited microbes. Metagenomic analysis of DNA derived from the inner tissues of healthy plants showed a great diversity of microbial organisms within the plant host $[2,3,6,11]$; even grown aseptically in laboratory plants exhibit systemic colonization of the endosphere. Endophytic community members directly or distantly communicate between themselves and with the plant host, using physico-chemical signals, and are doomed to be either integrated into the plant information web or at least to interplay with it. There are several indirect lines of evidence to believe that endophytes are acceptors and enhancers of environmental signals, as well as they are creators and mediators of intrinsic information.

First, endophytic microorganisms have multiple impacts on a plant micro-ecosystem functioning and may affect plant responses to various environmental changes, including climate (see rev. [1,9]). Second, both plants and microorganisms produce a wide array of similar metabolites, which have common precursors. For example, the universal precursors for isoprenoids (carotenoids, quinones, hormones and secondary metabolites, that serve in plant defense and communication) may be produced in two ways, and both of them are widespread in eubacteria and archaea [13]. The hypothesis of xenohormesis proposed by Howitz and Sinclair [14] states that stress-induced molecules from plants can be sensed by microorganisms, which obviously are capable to produce similar secondary metabolites. According to this hypothesis, plants and mic- 
roorganisms possess homologous gene clusters (probably, being horizontally transferred between domains) and thus might be cross-activated by plant hosts or endophytes under some emergency $(e . g$. pathogen attack). It is a well known example of the same bioactive compounds synthesis by medicinal plants and endophytic bacteria or fungi, residing in these plants (taxol, for instance, producing by fungi [15]). Third, endophytes possess certain instruments of interaction with plant hosts similar to another plant-associated microorganisms. Commonalities in endophytes and pathogens seen, $e . g$. in availability of type III or IV protein secretion systems [16, 17], which they may use for adaptation in the plant host. However, the question remains, concerning the functionality of these systems. The horizontal acquisition of type IV secretion system is known in the nature and presumably may occur in the endophytosphere. For example, in the endophytic Klebsiella pneumonia, genetic determinants for such secretion system are located within integrated mobile element and could be acquired via a gene transfer mechanism [16]. Finally, it was documented in many laboratories, that the indigenous endophytic microbial communities sense external cues, modulating a community structure under the impact of biotic or abiotic factors on the plant system [12, 18-24].

How adaptive social interactions evolve in the endophytosphere? What are the parameters, governing the success of cooperative traits? How microbial organisms mount own information web within authentic plant information continuum? Is there the cross-talk between endophytes and the plant host within information processing networks? To address these questions, we first need to outline briefly the authentic information processing system in plant host and then to provide some careful prognosis about a cross-talk between endophytes and the plant partner, as the role of endophytes in the plant information processing networks has no yet a solid foundation. Nevertheless, important insights may be obtained from the analysis of the impact of other plant-associated bacteria on information processing in the plant system, mainly pathogens and their non-pathogenic mutants.

Information processing system in plants as alternative to neuronal network. Information is encoded signals, incoming to the living organism from outside or being induced inside and spreading over signaling cascades to a target cell. The plant information network is hierarchically organized due to sub-systems at each organizational level, which allow to process signals in the plant interior and re-distribute there in some other form [25]. Plants permanently meet the environmental challenges, which cannot avoid (the gravitational force, the influence of the Moon, vibrations, irradiations, temperature, pathogens etc.) and need to adapt itself to permanent challenges. While they don't have a real neuronal network, individual plants have sensory receptors, ion channels, vessels, which have certain features of a «nervous» system [24] and may represent specific kind of a proto-nervous system in plants [26]. It can perform subsequent transformation of accepted signals in the form of plant-specific information, using the regulatory molecules, such as plant hormones, receptor kinases, transcription factors, small non-coding RNAs, etc. (reviewed in [27]). Another class of intrinsic modulators of signals is the bioelectric impulses being derived from ionic exchanges across membranes and channeled within a phytoneural system [25]. There might be a «decision-making» process, prioritizing one type of response above others; recognized and encoded information is transferred to the nucleus, where plant response is regulated at the levels of transcription, translation and posttranslational events. In addition to processes, occurring in nuclea, the apo- and aloplastic information processing play a critical role in regulating integrative functions in plants.

Some acquired valuable information is stored by plants in order to update their behavior and survive future challenges; in other words, plants induce a «memory» via epigenetic mechanisms (reviewed in [28]).

Individual plant cells have acquired highly autonomous capabilities in sense of information processing. The question rises, how molecular networks at the single-cell level ultimately define collective cell behaviors? The understanding, how interaction among cells proceeds, enabling the spread of signals within information processing networks, is a fundamental problem in biology. The closely related question is, how this autonomous cell system mediates the regulation of functions across the plant, including growth, defense, and adaptation to the environment, and how this system 
cross-talk with information processing networks of associated microbes?

Endophytes as putative components of the information processing network in a plant system. Signal perception and transmission. In a hierarchy of the plant information-processing system, the sub-systems, which recognize, percept, and transmit signals, take a central place. In plant systems, perception and transmission of biochemical signals occur mostly through two mechanisms: (i) protein-protein interactions and enzymatic reactions such as protein phosphorylation and dephosphorylation or (ii) protein degradation or production of intra-cellular messengers. There are two stages in proteinprotein interactions: (i) a cell surface receptor should be activated by an extracellular signaling molecule; (ii) this receptor alters a second messenger, mounting a response. One of the systems, sensing and responding to environmental cues, is a histidine kinase-based signaling system, which plants use to relay signals [29]. Autophosphorylating histidine protein kinases provide phosphoryl groups for response regulator proteins, and phosphorylation induces so far a conformational change in the regulatory domain that results in the activation of an associated domain and a switch on of the response or further signal transmission. The ectodomain of plant receptor kinase functions in different signaling pathways, including symbiosis and defense [30]. In apoplast, environmental signals, e. g. chitin, peptidoglycan etc. (MAMPs) (see on-line glossary at www. biopo lymers.org.ua doi: 10.7124/bc.00081D) are being recognized, accepted and transported across a cell wall and membrane to tissues/organ, so far the apoplast is involved in a cell-to-cell communication. Here, hormones interact with cell-surface recep-tors, and microorganisms trigger a local or systemic acquired resistance, i. e. this is a place, where intensive information recognition and decoding-encoding events take place. Both apo- and aloplasts are occupied by endophytes [31, 32], which might be involved in plant programs, and in these settings, a cross-talk with the authentic plant information processing network may occur.

In bacteria, in analogy to plants, there is the autophosphorylation of histidine residue on the ectodomain and a phosphor-transfer from there to an aspartate residue on the response regulator. It was shown, that histidine kinase modules are evolutionarily conserved bet- ween plants and bacteria. Phylogenetic analysis indicated that two-component systems (TCSs) originated in domain Bacteria and were radiated to domains Archaea and Eukarya via multiple lateral transfer events. This observation is also supported by greater abundance and wider distribution of TCS in Bacteria, in comparison to Archaea and Eukarya (reviewed in [33]). One such feature is the integration of TCS signaling pathways with other signaling systems of eukaryotes: bacterial histidine kinase components have been shown to be functional in plants and vice versa [34]. This may mean that in some cases, bacterial TCSs can be integrated into plant information processing events, when some signals in endophytosphere can be captured by bacteria or when indigenous bacteria amplify plant hormonal signals by own resources, being involved in some event of joint interest (e.g. defense).

Scaffolding: is there commonality in pathogens and endophytes? Environmental cues are perceived and transmitted by a myriad of plant signal transduction pathways; by turning on specific transcription factors in the nucleus this leads to the activation of genes, encoding proteins, that enable plant adaptation to environmental challenges. Many of these genes are more often regulated by the modulation of scaffold protein properties than by the activities of integral components in the signaling cascades. This strategy enables signal transmission to be turned on or off rapidly or to be tuned to the cues via the assembly or disassembly of the complexes of plant scaffold protein with bacterial effector molecule. Actually, the manipulation of scaffolding represents the intimate type of plant-microbial interactions. Some bacterial factors use plant scaffold proteins to become active, while others target the host scaffold proteins to suppress its activity. For example, the interaction between the HopQ1 effector secreted by Pseudomonas syringae pv. phaseolicola and a specific plant protein is needed for modulating the properties of this bacterial effector in planta and spreading through the plant [35]. The outcome of the scaffolding depends on the competition between processes mediated by the plant and bacteria. When HopQ1 enters plant cells, it is recognized by the immune system, which prevents infection. However, being phosphorylated, the effector suppresses plant defense, and a spreading across the plant depends on the speed of phosphorylation-dephosphorylation processes. Transcription fact- 
ors, which are used in the plant system to coordinate gene expression, might be imitated by bacteria to induce developmental gene reprogramming on their benefit [35]. In this relation, plants are not complete losers and also use such a strategy, secreting compounds that mimic the bacterial signals and thereby may confuse bacterial activity [37].

Role of bacterial bioactive molecules in the regulation of biological processes in plants. The metabolomes of plants include thousands of bioactive compounds, which significantly exceed those of prokaryotes or animals. However, there is a room for microbially produced biologicals in the plant information web. The metabolome of bacterial cells consist of thousands metabolites, referring to genome-based metabolic network models [38]. Microbes utilize this great variety of metabolites to perform fundamental processes (population maintenance, defense, intra- and interspecies communication etc.). Small bacterial bioactive molecules such as hormones, autoinducers, volatiles etc. act as signals to recognize the environment and coordinate physiological processes in the contact with surrounding. Some of these molecules could be used by microbial organisms to manipulate the plant physiology, silencing hormone-mediated signaling or amplifying plant signals by own hormones.

Plant hormones have a designation to collectively regulate every aspect of plant life, from pattern formation during development to responses to biotic and abiotic stressors [39]. These low-molecular-weight compounds abscisic acid (ABA), auxins, brassinosteroids, cytokinin, gibberellic acid, ethylene, jasmonic acid (JA), salicylic acid, several peptide hormones act as systemic signals, transmitting information over large distances. Hormonal signaling pathways are known to interact at the level of gene expression. Studies show that there is overlap between phytohormones, as well as between hormones originated from plants and microorganisms.

Bacteria manipulate plant development by interfering with the plant's own growth hormones, in particular, with auxins. For example, rhizobia reduce the auxin transport, exploiting flavonoids, which have been suggested as potential auxin transport inhibitors [40]. Another intriguing example illustrates, how a bacterial component of flagella positively contributes to MAMP- triggered immunity by silencing auxin receptors and subsequently suppressing auxin signaling [41]. Bacteria manipulate also the components of another plant hormone signaling pathways (ABA and JA) and do this via miRNAs [42].

Quorum sensing and communications within endophytosphere. The produced by the plant host hormones can cross-signal with quorum sensing (QS) signals to modulate bacterial or fungal gene expression. QS-signaling may represent an example of the integrative network of signal processing in plants and takes important position in the global information processing network. Plants can recognize, uptake, degrade or quench microbial signaling molecules - autoinducers [43]. Microbes produce and detect the latter in order to recognize self and non-self, as well as to synchronize cells for the execution of specific functions like production of enzymes, conjugation, biofilm formation etc. under a threshold concentration of autoinducers [44]. In the endophytosphere, the benefits from secreted substances such as QS molecules seem to be much lower because autoinducers commonly diffuse not so far away from producers. Endophytes utilize AI-1 or AI-2 systems [45, 46] or unknown yet QS [47] and, theoretically, may increase a pool of signaling molecules by incoming endophytes or activated (re-awaken) resident populations. QS regulates cell-cell communications within a single population, as well as inter-species and inter-kingdom interactions between bacteria, fungi, and plants [43]. Recent results show that QS has a prominent role in interrelationships between the plant and endophytes [48, 49]. The composition and abundance of autoinducers may modulate cultivar-specific plant responses, $e$. $g$. a bacterial strain with quenched QS signal had a great impact on gene expression in the host plant, as compared to a wild strain [48].

In the plant endosphere, synergism among different bacterial species in the interspecies signaling is a highly probable $[19,49]$. With certain presumption, we may speculate about synergistic effects in endophytic microbiome between community members, producing the same type signaling molecules, or the donation them to species, which have no a quorum of autoinducers in small endophytic populations. In theory, QS signal molecules may provoke resuscitation from dormant state in endophytes, gaining signs of emergency from the envi- 
ronment. The question rises again, how endophytes sense external signals?

Resuscitation of endophytic persisters: an interplay with plant information processing? The metagenomic approach to a study of microbial communities has opened an unprecedented variety of uncultivable endophytes. It was shown, in particular, that their diversity exceeds that of the cultivable bacteria isolated from plant tissues on Petri plates [50-54]. In general, the uncultivable bacteria originated from environmental samples fall in either a category for which appropriate laboratory conditions necessary for growth are not identified yet, or a category that requires the removal or addition of certain factors to re-initiate growth [55]. Many bacterial species are able to enter into a state of dormancy, in which cells can persist for extended periods without division. Persisters resist acids, multi-drug action, osmotic stress, oxidation etc. [56] and reach this without any genetic change. The reversibility of this state enables dormant organisms to «re-awaken» or resuscitate under conditions permissive to re-growth.

Signaling molecules such as cyclic adenosine monophosphate and $\mathrm{N}$-acyl-homoserine lactones were shown to be responsible for resuscitation from a dormant state; in addition, the resuscitation-promoting factors (Rpf) can stimulate growth after exiting the VBNC state (reviewed in [57]). Rpfs are the member of a family of secreted proteins found throughout the Actinobacteria and in Firmicutes species, which produce peptidoglycans from the cell wall that could exert bacterial signaling $[58,59]$. Growth factors used for the resuscitation of non-dividing cells are not limited to the described species and obviously can be associated with resuscitation of plant-associated microbiota. The high level of persistence is favored by great competition for resources, and it may be predicted in the endophytosphere. Persistence provides a direct benefit for populations by producing a sub-population that reduces local competition for resources and preventing therefore the spread of strains with a poor fitness. Certain (dormant) endophytic populations of microbes may sense a lack of signals needed to perform any physiological functions in the endophytosphere, in contrast to active sub-populations, which are more plant-«devoted» and capable to fulfill beneficial functions, $e . g$. nitrogen fixation [60-62]. On the other hand, the host may keep endophytic microbial populations small, preventing their proliferation with specific regulators, destroying or quenching microbial regulators [49]. The maintenance of dormant sub-populations may be a hidden strategy in the plant system survival, and a mechanism of re-growth of dormant population may serve a plantmicrobial cooperation under stressful conditions. Actually, the formation of persister cells is not reported for endophytes yet. In line with this, in the pathogenic bacterium Xanthomonas fastidiosa, the formation of persister phenotype under stressful conditions is recently discovered [63].

The expression of toxin-antitoxin (TA) systems directly correlates with the persistence phenotype, inducing in microbes under unfavorable conditions [64]. Stress conditions result in the degradation or depletion of the antitoxin and the disturbance of the TA balance, leading to the delay of main cellular processes and dormancy. TA loci are highly abundant in free-living, but lost from host-associated prokaryotes [65]. Nevertheless, the TA systems were detected in complete genomes of endophytic bacteria [66,67], including obligate endophyte Herbaspirillum seropedicae, and presumably TA systems exist in all endophytic species, but remain uncovered yet. Relaying on a big body of evidence, which exhibit the modulation of endophytic microbiome under impact of different external cues [12, 18, 19, 21-23, 51, 67], it can be presumed that both known and uncovered yet (bio)physical and (bio)chemical signals are involved in «awakening» and synchronization of microbes in endophytosphere.

Epigenetic manipulations by bacteria in the plant system. Epigenetic mechanisms include DNA methylation and post-translational modifications of histones and serve the regulation of gene expression during plant development, defense, and exposure to stresses (reviewed in [68]). Plants perceive both abiotic and biotic stresses within a life-time, «memorize» them via epigenetic mechanisms, and save this «memory» for next generations [69-71]. In bacteria, epigenetic mechanisms control DNA replication and gene expression, the packaging of bacteriophage genomes, transposase activity, a stressinduced variability of bacteria [72].

The role of epigenetic mechanisms in shaping hostmicrobial interactions has received not enough attention, except interactions between hosts and pathogens (see rev. [73]). The latter involve a recombination bet- 


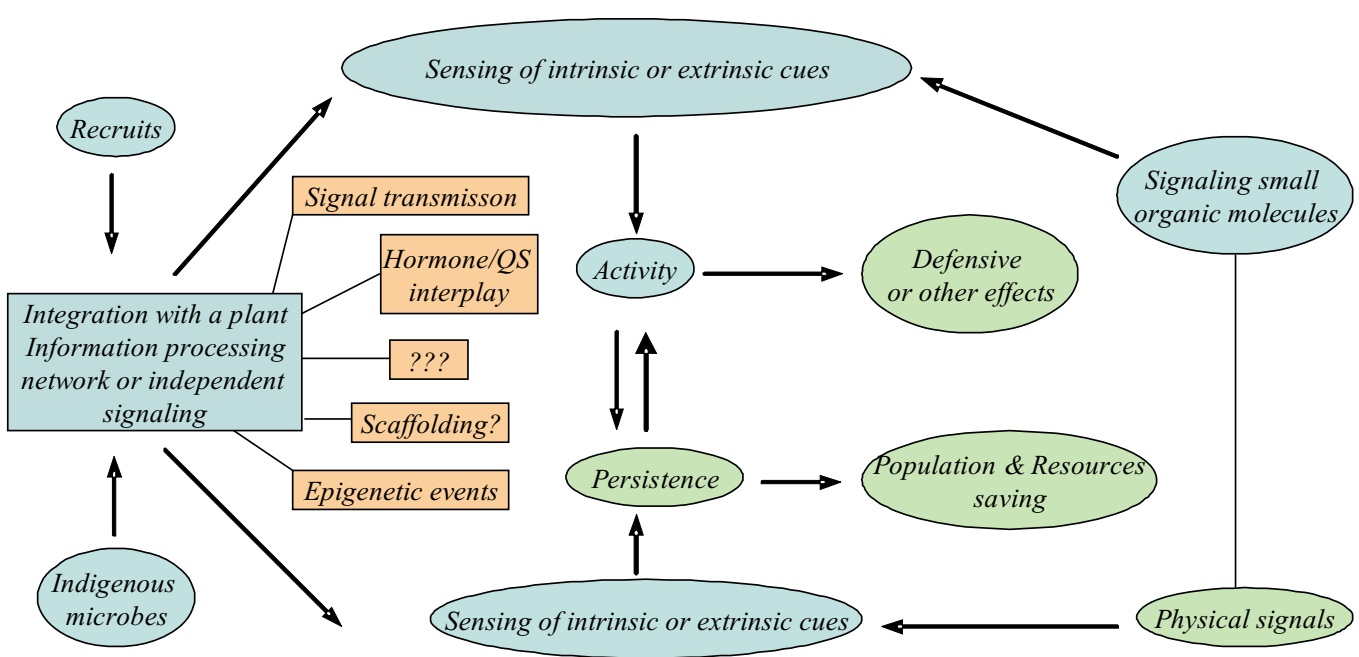

Putative scenarios of the endophytic microbiome involvement in plant information processing networks ween transposon elements and sequence repeats, encoding resistance proteins; via recombination events microbes involved in the extensive reprogramming of plant transcription and formation of trans-generation «memory», which fixes interaction with microbes for descendants [74]. Another mechanism of a plant-microbial interrelationship is DNA methylation-demethylation, potentially acting to prime transcriptional activation of some resistance genes linked to transposable elements [75]. Exposed to bacterial plants pathogen or avirulent bacteria reveal numerous stress-induced differentially demethylated regions associated with differentially expressed defense-related genes [76]. The epigenetic changes suggest that the epigenome may help organisms to develop resistance to pathogens [80] and to other environmental stressors [78]. In a similar way, endophytic bacteria induce DNA methylation-demethylation in plant hosts. Recently, Da et al. [79] reported the first evidence exhibited cytosine methylation polymorphisms in potato plant DNA as a response to the bacterial endophyte Burkholderia phytofirmans PsJN. The DNA methylation levels in different potato varieties differed and depended on their responsiveness to endophyte: a highly responsive to the bacterium variety exhibited a little change in the overall cytosine methylation pattern, but a poorly-responsive variety exhibited significantly higher levels of overall cytosine methylation and a decrease in the number of non-methylated sites in the bacterized plants compared to controls. In this case, the DNA methylation level correlated with bacterial effects on the plant host.
In plant endosphere, bacteria-fungal interactions may be relevant to epigenetic events. Fungi use the mechanism of histone post-translational modification to modulate the transcription of genes involved in secondary metabolite production [80]. External epigenetic modifiers may re-program biosynthetic pathways and activate secondary metabolite genes resulted in the enhanced production of secondary metabolites. In the study [81], bacteria were shown to perform a role of epigenetic modifiers in interactions with eukaryotic partners: histone acetylation occurred during the interaction of the fungus Aspergillus nidulans and the bacterium Streptomyces rapamycinicus. In the result, the fungus activated suppressed genes and produced secondary metabolites, orsellinic acid and its derivatives, known as radical scavengers. The nature of the compound, promoting histone modification, is unknown yet; however, it was proven that for this action a physical contact of fungal hyphae with bacterial cells was obligatory.

Summarizing, I would like to refer a reader to Figure, where putative scenarios of the endophytic microbiome involvement in the plant information processing network is schematically displayed. It is obvious, that the scenarios are based on scarce information available and do not fully reflect a reality. To know more, this review emphasizes the need to invest efforts in the study of the processing of information under assistance of microbial organisms as this will lead not only to intriguing discoveries on the level of molecular biology, quantum physics etc., but to a design of new green technologies of plant protection and other technological breakthroughs. 


\section{Н. О. Козировська}

Перехресні взаємодії між ендофітами та рослиною-хазяїном у мережах інформаційного процесингу

\section{Резюме}

Рослини густо населені про- та евкаріотними мікроорганізмами $i$, отже, являють собою біологічну систему надзвичайної складності. Ця система з доволі непростими процесами комунікачії, що відбуваються вздовж усієї рослини, існує для обробки інформації. Мережева обробка інформації у рослин є основою для таких проиесів, як ріст, захист і пристосування до навколишнього середовища. Молекулярні механізми, що лежать в основі сприйняття, передачі, аналізу та зберігання ендогенної $і$ зовнішньої інформаиії всередині рослини, ще належить повністю з'ясувати. Асоиійовані з рослиною мікроорганізми та їхній внесок в обробку інформації дослідники часто ігнорують. Ендофіти як партнери рослини є необхідною інтегративною частиною ї̈ системи. Різноманітні ендофітні мікроорганізми являють собою «нормальну» мікрофлору, яка відіграє важливу роль в імунітеті рослин і допомагає їм вижити у навколишньому середовищі (захист, живлення, детоксикаиія тошо). Певну роль ендофітної мікробіоти в обробиі інформацї можна припустити, беручи до уваги ко-еволюцію рослинно-мікробних систем та емпіричні дані. Оскільки в літературі починають з'являтися публікаиії на иңю тему, в представленому огляді розглянуто ключові роботи в галузі взаємодї рослин з ендофітами у контексті обробки інформації і висловлено думку стосовно їхньої прогнозованої ролі в інформаційній мережі рослин за умов захисту та пристосування останніх до змінених умов та налаштування відповідної поведінки рослини.

Ключові слова: рослина як система, ендофіти, обробка інформації, захист рослин, пристосування.

\section{Н. А. Козыровская}

Перекрестные взаимодействия между эндофитами и растением-хозяином в сетях информационного процессинга

\section{Резюме}

Растения густо населены про- и эукариотными микроорганизмами и, таким образом, представляют собой биологическую систему чрезвычайной сложности. Эта система с довольно непростыми проиессами коммуникаиии, проходящими в растении, существует для обработки информации. Сетевая обработка информации у растений служит основой для таких процессов, как рост, защита и приспособление к окружающей среде. Молекулярные механизмы, лежашие в основе восприятия, передачи, анализа и сохранения эндогенной и внешней информации внутри растения, еще предстоит выяснить. Ассочиированные с растением микроорганизмы и их вклад в обработку информации исследователи часто игнорируют. Эндофиты как партнеры растений являются необходимой интегративной частью ее системы. Разнообразные эндофитные микроорганизмы - это «нормальная» микрофлора, выполняющая важную роль в иммунитете растений и помогающая им выжить в окружающей среде (защчтта, питание, детоксикация и др.). Определенную роль эндофитной микробиоты в обработке информацмм можно предположить, приняв во внимание ко-эволюиию растительно-микробных систем, а также эмпирические данные. Поскольку в литературе начинают появляться публикации на эту тему, в представленном обзоре рассмотрены ключевые работы в области взаимодействия растений с эндофитами в контексте обработки информации и изложено мнение об их прогнозируемой роли в информаџионной сети растений в условиях защиты и проспособления последних к измененным условиям и настройке соответствующего поведения растения.

Ключевые слова: растение как система, эндофиты, обработка информации, защчта растений, приспособление.

\section{REFERENCES}

1. Friesen M., Porter S. S., Stark S. C. et al Microbially mediated plant functional traits // Annu. Rev. Ecol. Evol. Syst.-2011.42.-P. 23-46.

2. Lundberg D. S., Lebeis S. L., Paredes S. H. et al. Defining the core Arabidopsis thaliana root microbiome // Nature.-2012.-488, N 7409.-P. 86-90.

3. Bodenhausen N., Horton M. W., Bergelson J. Bacterial communities associated with the leaves and the roots of Arabidopsis thaliana // PLoS One.-2013.-8, N 2.-e56329.

4. Johnston-Monje D., Raizada M. N. Conservation and diversity of seed associated endophytes in Zea across boundaries of evolution, ethnography and ecology // PLoS One.-2011.-6, N 6.e20396.

5. Hardoim P. R., Andreote F. D., Reinhold-Hurek B. et al. Rice root-associated bacteria: insights into community structures across 10 cultivars // FEMS Microbiol. Ecol.-2011.-77, N 1.P. 154-164.

6. Bulgarelli D., Rott M., Schlaeppi K. et al. Revealing structure and assembly cues for Arabidopsis root-inhabiting bacterial microbiota // Nature.- 2012.-488, N 7409.-P. 91-95.

7. Nadell C. D., Xavier J. B., Foster K. R. The sociobiology of biofilms // FEMS Microbiol. Rev.-2009.-33, N 1.-P. 206-224.

8. Rosenblueth M., Martinez-Romero E. Bacterial endophytes and their interactions with hosts // Mol. Plant-Microbe Interact.2006.-19, N 8.-P. 827-837.

9. Porras-Alfaro A., Bayman P. Hidden fungi, emergent properties: endophytes and microbiomes // Ann. Rev. Phytopathol.-2011.49.-P. 291-315.

10. Podolich O., Laschevskyy V., Ovcharenko L. et al. Methylobacterium sp. resides in unculturable state in potato tissues in vitro and becomes culturable after induction by Pseudomonas fluorescens IMGB163 // J. Appl. Microbiol. -2009.-106, N 3.-P. 728-737.

11. Jumpponen A., Jones K. L. Massively parallel 454 sequencing indicates hyperdiverse fungal communities in temperate Quercus macrocarpa phyllosphere // New Phytol.-2009.-184, N 2.P. 438-448.

12. Ardanov P., Sessitsch A., Haggman H. et al. Methylobacteriuminduced endophyte community changes correspond with protection of plants against pathogen attack // PLoS ONE-2012.-7, N 10.-e46802.

13. Kirby J., Keasling D. Biosynthesis of plant isoprenoids: Perspectives for microbial engineering // Annu. Rev. Plant Biol.2009.-60.-P. 335-355.

14. Howitz K. T., Sinclair D. A. Xenohormesis: sensing the chemical cues of other species // Cell.-2008.-133, N 3.-P. 387-391.

15. Zhou X., Zhu H., Liu L. et al. A review: recent advances and future prospects of taxol-producing endophytic fungi // Appl. Microbiol. Biotechnol.-2010.-86, N 6.-P.1707-1717.

16. Fouts D. E., Tyler H. L., DeBoy R. T. et al. Complete genome sequence of the $\mathrm{N}_{2}$-fixing broad host range endophyte Klebsiella pneumoniae 342 and virulence predictions verified in mice // PLoS Genet-2008.-4, N 7.-e1000141.

17. Han J.-I., Choi H.-K., Lee S.-W. et al. Complete genome sequence of the metabolically versatile plant growth-promoting en- 
dophyte, Variovorax paradoxus S110 // J. Bacteriol.-2011.-193, N 5.-P. 1183-1190.

18. Reiter B., Pfeifer U., Schwab H., Sessitsch A. Response of endophytic bacterial communities in potato plants to infection with Erwinia carotovora subsp. atroseptica // Appl. Environ. Microbiol.-2002.-68, N 5.-P. 2261-2268.

19. Andreote F. D., Lacava P. T., Gai C. S. et al. Model plants for studying the interaction between Methylobacterium mesophilicum and Xylella fastidiosa // Can. J. Microbiol.-2006.-52, N 5.P. 419-426.

20. Podolich O. V., Lytvynenko T., Voznyuk T. M. et al. Detection of endophytic bacteria communities in aseptic potato plants after inoculation with Pseudomonas sp. IMBG163// Proc. Uzhgorod State Univ.-2006.-N 18.- P. 165-170.

21. Thomas P., Swarna G. K., Patil P., Rawal R. D. Ubiquitous presence of normally non-culturable endophytic bacteria in field shoot-tips of banana and their gradual activation to quiescent cultivable form in tissue cultures // Plant Cell Tiss. Org. Cult.2008.-93, N 1.-P. 39-54.

22. Andreote F. D., de Arautjo W. D., de Azevedo J. L. et al. Endophytic colonization of potato (Solanum tuberosum L.) by a novel competent bacterial endophyte, Pseudomonas putida strain P9, and its effect on associated bacterial communities // Appl. Environ. Microbiol.-2009.-75, N 11.-P. 3396-3406.

23. Lian J., Wang Z., Zhou S. Response of endophytic bacterial communities in banana tissue culture plantlets to Fusarium wilt pathogen infection // J. Gen. Appl. Microbiol.-2008.-54, N 2.P. 83-92.

24. Conn V. M., Walker A. R., Franco C. M. Endophytic actinobacteria induce defense pathways in Arabidopsis thaliana // Mol. Plant-Microbe Interact.-2008.-21, N 2.-P. 208-218.

25. Barlow $P$. W. Reflections on "plant neurobiology» // BioSystems.2008.-92, N 2.-P. 132-147.

26. Oyarce P., Gurovich L. Evidence for the transmission of information through electric potentials in injured avocado trees // J. Plant Physiol.-2011.-168, N 2.-P. 103-108.

27. Busch $W$., Benfey $P$. N. Information processing without brains the power of intercellular regulators in plants // Development.2010.-137.-P. 1215-1226.

28. Hauser M. T., Aufsatz W., Jonak C., Luschnig C. Transgenerational epigenetic inheritance in plants // Biochim. Biophys. Acta.2011.-1809, N 8.-P. 459-468.

29. Stock A. M., Robinson V. L., Goudreau P. N. Two-component signal transduction // Annu. Rev. Biochem.-2000.-69.-P. 183-215.

30. Antolin-Llovera M., Ried M. K., Binder A., Parniske M. Receptor kinase signaling pathways in plant-microbe interactions // Annu. Rev. Phytopathol.-2012.-50.-P. 451-473.

31. Belyavskaya N. O., Kozyrovskaya N. O. et al. Interrelations of the Klebsiella genus with the plant. 1. Electron microscopic analysis of endophytic microorganisms interrelationship with rice seedlings roots // Biopolym. Cell.-1995.-11, N 1.-P. 55-60.

32. Thomas P., Reddy K. Microscopic elucidation of abundant endophytic bacteria colonizing the cell wall - plasma membrane peri-space in the shoot-tip tissue of banana // AoB Plants.2013.-5.-doi: 10.1093/aobpla/plt011.

33. Wuichet K., Cantwell B. J., Zhulin I. B. Evolution and phyletic distribution of two-component signal transduction systems // Curr. Opin. Microbiol.-2010.-13, N 2.-P. 219-225.

34. Morey K. J., Antunes M. S., Albrecht K. D. et al. Developing a synthetic signal transduction system in plants // Methods Enzymol.-2011.-497.-P. 581-602.

35. Giska F., Lichocka M., Piechocki M. et al. Phosphorylation of HopQ1, a type III effector from Pseudomonas syringae, creates a binding site for host 14-3-3 proteins // Plant Physiol.-2013.161, N 4.- P. 2049-2061.

36. Nissan G., Manulis-Sasson S., Weinthal D. et al. The type III effectors HsvG and HsvB of gall-forming Pantoea agglomerans determine host specificity and function as transcriptional activators // Mol. Microbiol.-2006.-61, N 5.-P. 1118-1131.

37. Bauer W. D., Mathesius U. Plant responses to bacterial quorum sensing signals // Curr. Opin. Plant Biol.-2004.-7, N 4.- P. 429-433.

38. Durot M., Bourguignon P. Y., Schachter V. Genome-scale models of bacterial metabolism: reconstruction and applications // FEMS Microbiol. Rev.-2009.-33, N 1.-P. 164-190.

39. Bishopp A., Mahonen A. P., Helariutta Y. Signs of change: hormone receptors that regulate plant development // Development.-2006.-133.-P. 1857-1869.

40. Wasson A. P., Pellerone F. I., Mathesius U. Silencing the flavonoid pathway in Medicago truncatula inhibits root nodule formation and prevents auxin transport regulation by rhizobia // Plant Cell.-2006.-18, N 7.-P. 1617-1629.

41. Navarro L., Dunoyer P., Jay F. et al. A plant miRNA contributes to antibacterial resistance by repressing auxin signaling // Science.-2006.-312, N 5772.-P. 436-439.

42. Zhang $W$., Gao S., Zhou X. et al. Bacteria-responsive microRNAs regulate plant innate immunity by modulating plant hormone networks // Plant Mol. Biol.-2011.-75, N 1-2.-P. 93-105.

43. Hartmann A., Schikora A. Quorum sensing of bacteria and transkingdom interactions of $\mathrm{N}$-acyl homoserine lactones with eukaryotes // J. Chem. Ecol.-2012.-38, N 6.-P. 704-713.

44. Zuciga A., Poupin M. J., Donoso R. A. et al. Quorum sensing and 3 -indole acetic acid degradation play a role in colonization and plant growth promotion of Arabidopsis thaliana by Burkholderia phytofirmans PsJN // Mol. Plant-Microbe Interact.-2013.26, N 5.-P. 546-553.

45. Sessitsch A., Hardoim P., During J. et al. Functional characteristics of an endophyte community colonizing rice roots as revealed by metagenomic analysis // Mol. Plant-Microbe Interact.2012.-25, N 1.-P. 28-36.

46. Rezzonico F., Smits T. H., Duffy B. Detection of AI-2 receptors in genomes of Enterobacteriaceae suggests a role of type-2 quorum sensing in closed ecosystems // Sensors.-2012.-12, N 5.P. 6645-6665.

47. Hauberg-Lotte L., Klingenberg H., ScharfC. et al. Environmental factors affecting the expression of pilAB as well as the proteome and transcriptome of the grass endophyte Azoarcus sp. strain BH72 // PLoS ONE.-2012.-7, N 1.-e30421.

48. Trognitz F., Scherwinski K., Fekete A. et al. Interaction between potato and the endophyte Burkholderia phytofirmans // Tagung 59 der Vereinigung der Pfl Anzenzuchter und Saatgutkaufleute Osterreichs.-Raumberg-Gumpenstein, 2008.-P. 63-66.

49. Hosni T., Moretti C., Devescovi G. et al. Sharing of quorum-sensing signals and role of interspe- cies communities in a bacterial plant disease // ISME J.-2011.-5, N 12.-P. 1857-1870.

50. Garbeva P., van Overbeek L. S., van Vuurde J.W. L., van Elsas $J$. D. Analysis of endophytic bacterial communities of potato by plating and denaturing gradient gel electrophoresis (DGGE) of 16S rDNA based PCR fragments // Microb. Ecol.-2001.-41, N 4.-P. 369-383.

51. Podolich O. V., Ardanov P. E., Voznyuk T. M. et al. Endophytic bacteria from potato in vitro activated by exogenic non-pathogenic bacteria // Biopolym. Cell.-- 2007.-23, N 1.-P. 21-27.

52. Koskimaki J. J., Hankala E., Suorsa M. et al. Mycobacteria are hidden endophytes in the shoots of rock plant [Pogonatherum paniceum (Lam.) Hack.] (Poaceae) // Environ. Microbiol. Rep.2010.-2, N 4.-P. 619-624. 
53. Manter D. K., Delgado J. A., Holm D. G., Stong R. A. Pyrosequencing reveals a highly diverse and cultivar-specific bacterial endophyte community in potato roots // Microb. Ecol.-2010.-60, N 1.P. $157-166$.

54. Lucero M. E., Unc A., Cooke P. et al. Endophyte microbiome diversity in micropropagated Atriplex canescens and Atriplex torreyi var griffithsii // PLoS ONE-2011.-6, N 3.-e17693.

55. Stokell J. R., Steck T. R. Viable but nonculturable bacteria // eLS.-Chichester: John Wiley \& Sons, Ltd., 2012.-DOI: 10. 1002/9780470015902.a0000407.pub2.

56. Hong S. H., Wang X., O'Connor H. F. et al. Bacterial persistence increases as environmental fitness decreases // Microb. Biotechnol.-2012.-5, N 4.-P. 509-522.

57. Puspita I. D., Kamagata Y., Tanaka M. et al. Are uncultivated bacteria really uncultivable? // Microbes Environ.-2012.-27, N 4.- P. 356-366.

58. Ravagnani A., Finan C. L., Young M. A novel firmicute protein family related to the actinobacterial resuscitation-promoting factors by non-orthologous domain displacement // BMC Genomics.-2005.-6.-P. 39.

59. Puspita I. D., Uehara M., Katayama T. et al. Resuscitation promoting factor (Rpf) from Tomitella biformata AHU 1821(T) promotes growth and resuscitates non-dividing cells // Microbes Environ.-2013--28, N 1.-P. 58-64.

60. Egener T., Hurek T., Reinhold-Hurek B. Endophytic expression of nif genes of Azoarcus sp. strain $\mathrm{BH} 72$ in rice roots // Mol. Plant-Microbe Interact.-1999.-12, N 9.-P. 813-819.

61. Kovtunovych G., Kovalchuk M., Lar O. et al. Use of the gusAand $l u x$-reporter genes in monitoring plant-bacteria interactions // Prospects and applications for plant-associated microbe: A laboratory manual part A: Bacteria / Eds S. Sovari, A. M. Pirttila.-Turku, 2008.-P. 214-218.

62. Cordeiro F. A., Tadra-Sfeir M. Z., Huergo L. F. et al. Proteomic analysis of Herbaspirillum seropedicae cultivated in the presence of sugar cane extract // J. Proteome Res.-2013.-12, N 3.P. 1142-1150.

63. Muranaka L. S., Takita M. A., Olivato J. C. et al. Global expression profile of biofilm resistance to antimicrobial compounds in the plant-pathogenic bacterium Xylella fastidiosa reveals evidence of persister cells // J. Bacteriol.-2012.-194, N 17.-P. 45614569 .

64. Schuster C. F., Bertram R. Toxin-antitoxin systems are ubiquitous and versatile modulators of prokaryotic cell fate // FEMS Microbiol. Lett.-2013.-340, N 2.-P. 73-85.

65. Pandey D. P., Gerdes $K$. Toxin-antitoxin loci are highly abundant in free-living but lost from host-associated prokaryotes // Nucleic Acids Res.-2005.-33, N 3.-P. 966-976.

66. Taghavi S., van der Lelie D., Hoffman A. et al. Genome sequence of the plant growth promoting endophytic bacterium Enterobacter sp. 638 // PLoS Genet-2010.-6, N 5.-e1000943.

67. Pedrosa F. O., Monteiro R. A., Wassem R. et al. Genome of Herbaspirillum seropedicae strain $\mathrm{SmR} 1$, a specialized diazotro- phic endophyte of tropical grasses // PLoS Genet.-2011.-7, N 5.-e1002064.

68. Mirouze M., Paszkowski J. Epigenetic contribution to stress adaptation in plants // Curr. Opin. Plant Biol.-2011.-14, N 3.P. 267-274.

69. Mathieu O., Reinders J., Caikovski M. et al. Transgenerational stability of the Arabidopsis epigenome is coordinated by CG methylation // Cell.-2007.-130, N 5.-P. 851-862.

70. Ardanov P., Liaschenko S., Podolich O. et al. The use of endophytic bacteria for adaptation of potato plants in vitro to ex vitro conditions for the protection of planting material from pathogens // Science and Innovations.-2010-6, N 6.-P. 51-55.

71. Slaughter A., Daniel X., Flors $V$. et al. Descendants of primed Arabidopsis plants exhibit resistance to biotic stress // Plant Physiol.-2012.-158, N 2.-P. 835-843.

72. Ni M., Decrulle A. L., Fontaine F. et al. Pre-disposition and epigenetics govern variation in bacterial survival upon stress // PLoS Genet-2012.-8, N 12.-e1003148.

73. Alvarez M. E., Nota F., Cambiagno D. A. Epigenetic control of plant immunity // Mol. Plant Pathol.-2010.-11, N 4.-P. 563-576.

74. Molinier J., Ries G., Zipfel C., Hohn B. Transgeneration memory of stress in plants // Nature.-2006.-442, N 7106.-P. 1046-1049.

75. Yu A., Lepurea G., Jayb F. et al. Dynamics and biological relevance of DNA demethylation in Arabidopsis antibacterial defense // Proc. Natl Acad. Sci. USA.-2013.-110, N 6. -P. 2389-2394.

76. Dowen R. H., Pelizzola M., Schmitz R. J. et al. Widespread dynamic DNA methylation in response to biotic stress // Proc. Natl Acad. Sci. USA.-2012.-109, N 32.-E2183-E2191.

77. Luna E., Bruce T. J., Roberts M. R.et al. Next-generation systemic acquired resistance // Plant Physiol.-2012.-158, N 2.P. 844-853.

78. Migicovsky Z., Kovalchuk I. Changes to DNA methylation and homologous recombination frequency in the progeny of stressed plants // Biochem. Cell Biol.-2013.-91, N 1.-P. 1-5.

79. Da K., Nowak J., Flinn B. Potato cytosine methylation and gene expression changes induced by a beneficial bacterial endophyte, Burkholderia phytofirmans strain PsJN // Plant Physiol. Biochem.-2012.-50, N 1.-P. 24-34.

80. Cichewicz R. H. Epigenome manipulation as a pathway to new natural product scaffolds and their congeners // Nat. Prod. Rep.-2010.-27, N 1.-P. 11-22.

81. Nutzmann H. W., Reyes-Dominguez Y., Scherlach K. et al. Bacteria-induced natural product formation in the fungus Aspergillus nidulans requires Saga/Ada-mediated histone acetylation // Proc. Natl Acad. Sci. USA.-2011.-108, N 34.-P. 14282-14287.

82. Winans $S$. C. A new family of quorum sensing pheromones synthesized using S-adenosylmethionine and Acyl-CoAs // Mol. Microbiol.-2011.-79, N 6.-P. 1403-1406.

83. Blekhman I. I. Synchronization in nature and technology.Moskow: Nauka, 1981.-351 p. 
- Endophytosphere - a plant interior.

- Epigenetic processes - heritable changes in gene expression that occur without changes in the DNA sequence.

- Interactome - in molecular biology, the whole molecular interactions that take place in an organism; in microbial ecology, the system of interactions between microbial organisms within the microbiome, as well as between the microbiome and the environment.

- Metabolome - the pool of small-molecule metabolites present in a biological cell, tissue, organ or organism as the end-products of cellular processes under specific physiological state.

- Metagenomic analysis - access to the genetic blueprint of communities of organisms via an array of genomic and bioinformatics tools.

- Microbe-associated molecular pattern (MAMP) - structurally conserved patterns that are specific for a taxonomic group of microbes and initiate immune responses in a counterpart (lipopolysaccharides, nucleic acids, flagellin, peptidoglucans etc.). In plants, MAMPs are usually perceived by cell surface pattern-recognition receptors.

- Microbiome - the totality of microbial organisms, occupying certain econiche.

- Pattern recognition receptor - host proteins that recognize MAMPs. These receptors are membrane-bound proteins, typically represented by two component receptor kinases.

- Persistence - a phenomenon of saving a species under unfavorable conditions by forming non-dividing cell sub-populations.

- Persisters - a small fraction of microbial cells in a dormant state that phenotypically differ from other cells in the population. Persisters have VBNC characteristics.

- Quorum sensing - a mechanism that regulates gene expression in response to cell density in microbial populations. Small diffusible molecules (N-acylhomoserine lactones, - quinolones and unsaturated fatty acids, linear and cyclic pep- tides etc.) play a role of regulators in QS (see rev. [82]).

- Synchronization - a characteristics of material objects to establish integrated rhythm of joint action in the specific network of signals, and so far this may coordinate events to operate a system in unison (I. Blekhman, [83]).

- The aloplast - the space outside cells within plant tissue.

- The apoplast - the extracellular compartment within plant wall.

- Toxin-antitoxin systems - small genetic elements found on plasmids or chromosomes of bacteria, archaea, and unicellular fungi. Typically, TA consists of two genes in one operon, encoding a stable toxin that disrupts an essential cellular process, and a labile antitoxin that neutralizes toxicity by binding to the protein or to the mRNA of the toxin under normal growth conditions.

- Two-component system, TCS - a sensor kinase that responds to specific signals and a cognate response regulator.

- VBNC (viable but not culturable) - resting, non-dividing microorganisms (bacteria, fungi) that require the removal or addition of certain factors to renitiate growth; they are not detectable by cultural methods. 